\title{
Le roman de Fauvel. Édition, traduction et présentation par Armand Strubel
}

\section{Graziella Pastore}

\section{(2) OpenEdition \\ 1 Journals}

\section{Édition électronique}

URL : http://journals.openedition.org/studifrancesi/2066

DOI : 10.4000/studifrancesi.2066

ISSN : 2421-5856

Éditeur

Rosenberg \& Sellier

\section{Édition imprimée}

Date de publication : 1 avril 2014

Pagination : 118

ISSN : 0039-2944

\section{Référence électronique}

Graziella Pastore, «Le roman de Fauvel. Édition, traduction et présentation par Armand Strubel », Studi Francesi [En ligne], 172 (LVIII | I) | 2014, mis en ligne le 01 avril 2014, consulté le 18 septembre 2020 URL : http://journals.openedition.org/studifrancesi/2066; DOI : https://doi.org/10.4000/studifrancesi. 2066

Ce document a été généré automatiquement le 18 septembre 2020.

\section{(c)}

Studi Francesi è distribuita con Licenza Creative Commons Attribuzione - Non commerciale - Non opere derivate 4.0 Internazionale. 


\title{
Le roman de Fauvel. Édition, traduction et présentation par Armand Strubel
}

\author{
Graziella Pastore
}

\section{RÉFÉRENCE}

Le roman de Fauvel. Édition, traduction et présentation par Armand STRUBEL, Paris, Librairie générale française («Le livre de poche», 32370. Lettres gothiques), 2012, pp. 703.

1 Poème satirique ancré dans l'héritage renardien, le Roman de Fauvel raconte l'histoire d'un cheval fauve, Fauvel, symbole de tous les vices, triomphant dans une société bestornee. Ce récit allégorique à succès, traditionnellement attribué au notaire royal Gervais du Bus, évoque ainsi la turbulente situation politique et sociale de la fin du règne de Philippe le Bel.

2 Parmi les 13 manuscrits qui nous sont parvenus, le ms. Paris, BnF, français 146 (f 1-45), qui fait l'objet de cette édition, constitue l'un des plus célèbres témoins de la littérature française du Moyen Age. Ce manuscrit transmet en fait une version enrichie par 78 enluminures ainsi qu'une «anthologie», attribuée à Chaillou de Pesstain, comportant de nombreuses interpolations lyriques latines et françaises accompagnées de leurs partitions. Cet ensemble remarquable de texte, image et musique a suscité l'intérêt de nombreux chercheurs, ce qui a comporté la parution de plusieurs éditions plus ou moins complètes tant de la partie narrative que de la partie musicale, ainsi que des éditions fac-similés (voir pp. 9-12). Cette nouvelle édition vise à offrir au public un «accès direct» à l'intégralité des éléments textuels du ms. fr. 146 (texte et additions lyriques) accompagnés d'une traduction.

3 Après une introduction qui analyse de manière détaillée la structure et les composantes du poème (pp. 7-109), l'éditeur énonce rapidement les principes d'établissement du texte (pp. 110-111), et fait le point sur les éditions et les études publiées (pp. 113-123). 
Le texte présente dans l'apparat les variantes du ms. Paris, BnF, fr. 2139, à la base de l'édition publiée par A. Langfors en 1914-1919 (pp. 125-683). Suivent deux annexes: Carmina burana «O varium fortunae» (pp. 687-688) et la liste des pièces musicales selon la Medieval Music Database (pp. 689-694). L'ouvrage est complété enfin par l'édition de trois échantillons des pièces musicales avec partition: conduit Vanitas vanitatum, Philippe le Chancelier (pp. 696-697); motet Veritas arpie/Iohanne, anonyme (pp. 698-699); motet Tribum/Quoniam/Merito hec patimur, Philippe de Vitry, (pp. 700-701). 